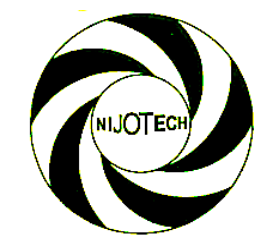

Nigerian Journal of Technology (NIJOTECH)

Vol. 37, No. 3, July 2018, pp. 656 - 662

Copyright@ Faculty of Engineering, University of Nigeria, Nsukka

Print ISSN: 0331-8443, Electronic ISSN: 2467-8821 www.nijotech.com

http://dx.doi.org/10.4314/njt.v37i3.14

\title{
DESIGN AND FABRICATION OF AN IMPROVED PLANTAIN PROCESSING MACHINE
}

\author{
J. 0. Oyejide ${ }^{1}$, K. E. Orhorhoro ${ }^{2,}$, S. C. Afoegba ${ }^{3}$ and M. Olaye ${ }^{4}$

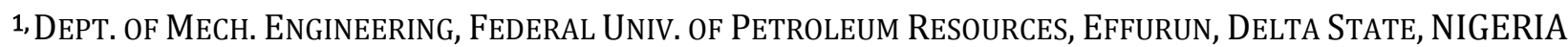 \\ 2, DEPARTMENT OF MECHANICAL ENGINEERING, IGBINEDION UNIVERSITY, OKADA, NIGERIA

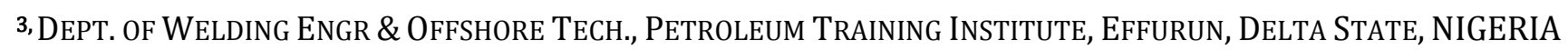 \\ 4, DePartment of Production EngineERing, University of Benin, BEnin City, Edo State, NiGERIA \\ E-mail addresses: ${ }^{1}$ oyejide.joel@fupre.edu.ng, ${ }^{2}$ ejiroghene.orhorhoro@eng.uniben.edu, \\ 3afoegbas@yahoo.ca,4olaye_messiah@yahoo.com
}

\begin{abstract}
Nigeria is the largest producer of plantain in West Africa with large percentage of it obtained in the southern part of the country. Plantains are of great nutritional importance, and the proximate analysis reported for plantain shows that per $100 \mathrm{~g}$ edible portion, plantains contain $67.30 \mathrm{~g}$ water, $116 \mathrm{kcal}$ of energy, and $31.15 \mathrm{~g}$ of carbohydrate. Although there are several machines that can process plantain but a complete machine that does pulverization, milling, drying, etc. is not readily available in Nigeria. In this research work, an improved plantain processing machine that comprises of all the units was designed and fabricated from available materials in Nigeria. $32 \mathrm{~kg}$ of plantains were thoroughly peeled, washed, sliced and loaded in the pulverizer unit which pulverized the sliced plantain into paste. The plantain paste was properly dried and ground to obtained plantain flour. Performance evaluation was carried out on the fabricated machine. The results of the performance evaluation show that force, torque, and power of 320N, $33.60 \mathrm{Nm}$, and $2533.7088 \mathrm{~W}$ were required for operation of the machine. Furthermore, the total mass of flour produced from $32 \mathrm{~kg}$ of plantain was $4.29 \mathrm{~kg}$. It was observed that mass of water in $32 \mathrm{~kg}$ of plantain was $19.25 \mathrm{~kg}$. The total mass of plantain pulp after addition of $5 \mathrm{~kg}$ of water was $37 \mathrm{~kg}$. These values were used to determine the percentage composition of water in the pulverized plantain pulp which was obtained as $65.54 \%$. Besides, the efficiency of the machine and machine throughput capacity were obtained as
\end{abstract}

Keywords: Plantain, Processing machine, Design, Fabrication, Flour, Pulverizer

Nomenclature

$A_{b}=$ Area of the blade $\left(\mathrm{m}^{2}\right)$

$\mathrm{A}_{0}=$ Area of pulverizer vessel $\left(\mathrm{m}^{2}\right)$

$\mathrm{D}=$ Shaft diameter $(\mathrm{mm})$

$\mathrm{D}_{\mathrm{m}}=$ Diameter of drum $(\mathrm{mm})$

$\mathrm{D}_{1}=$ Diameter of pulley one $(\mathrm{mm})$

$\mathrm{D}_{2}=$ Diameter of pulley two $(\mathrm{mm})$

$\mathrm{D}_{3}=$ Diameter of third pulley $(\mathrm{mm})$

$\mathrm{D}_{4}=$ Diameter of the fourth pulley $(\mathrm{mm})$

$\mathrm{D}_{\mathrm{p}}=$ Diameter of pulverizer vessel $(\mathrm{mm})$

$\mathrm{F}=$ Force $(\mathrm{N})$

$h_{\mathrm{hf}}=$ Heat transfer coefficients $\left(\mathrm{W} / \mathrm{m}^{2} \mathrm{~K}\right)$

$\mathrm{H}_{\mathrm{p}}=$ Height of cylinder vessel (mm)

$\mathrm{L}=$ Length of belt $(\mathrm{mm})$

$\mathrm{L}_{\mathrm{D}}=$ Length of drum (mm)

$\mathrm{M}=$ Maximum mass of plantain that the vessel can hold (kg)

MTC = Machine throughput capacity $(\mathrm{kg} / \mathrm{sec})$

$\mathrm{M}_{\mathrm{p}}=$ Mass of plantain (kg)

$\mathrm{M}_{\mathrm{w}}=$ Mass of water $(\mathrm{kg})$

$\mathrm{M}_{\mathrm{T}}=$ Total mass $(\mathrm{kg})$
$\mathrm{N}_{1}=$ Speed of electric motor (rpm)

$\mathrm{N}_{2}=$ Speed of the shaft (rpm)

$\mathrm{N}_{4}=$ Drum speed (rpm)

$\mathrm{P}=$ Power $(\mathrm{W})$

$\mathrm{P}_{1}=$ Mass of properly processed plantain flower $(\mathrm{kg})$

$\mathrm{P}_{2}=$ Mass of improper processed plantain flower $(\mathrm{kg})$

$\mathrm{t}=$ Drying time (sec)

$\mathrm{T}=$ Torque $(\mathrm{Nm})$

$\mathrm{V}_{\mathrm{o}}=$ velocity of paste flow $(\mathrm{m} / \mathrm{s})$

$\mathrm{V}=$ Maximum allowable capacity of the pulverizer vessel $\left(\mathrm{m}^{3}\right)$

$\mathrm{Q}=$ transported material flux $\left(\mathrm{kg} \mathrm{s}^{-1} \mathrm{~m}^{-2}\right)$

$\mathrm{Q}_{\mathrm{p}}=$ Pulverizer outlet flow rate $\left(\mathrm{kg} \mathrm{s}^{-1}\right)$

$\mathrm{X}=$ Centre distance between the two pulleys ( $\mathrm{mm})$

$\rho=\operatorname{Density}\left(\mathrm{kgs}^{-1}\right)$

$\eta_{\mathrm{p}}=$ Efficiency of plantain processing machine (\%)

\section{INTRODUCTION}

Plantain (Musa Paradisiaca) belongs to the family of plant known as Musceae. It is cultivated in the humid 
tropical zone of Africa, Asia, Central and Southern America including Latin America with a high quantity of production in Central and West Africa [1-2]. Just like yam, and cassava, plantain is highly produced in Nigeria [3-4]. Nigeria is the largest producer of the plant in West Africa with huge percentage of the cultivated plant obtained in southern part of the country [5]. Plantain is an extremely perishable crop. However, it can be processed and stored like flour [6].

Plantain can either be used for local consumption or used as byproducts for other production. When plantain is locally consumed, it plays a significant role in food and income security, and has the potential to contribute to national food security [7-8]. If plantain is processed into flour, the products obtained have nutritional and medicinal values which make plantain a highly sought-after product [9-10]. The flour obtained from processed plantain is a major source of iron, and it possesses other useful advantages over other starchy foods due to its protein, mineral and vitamins contents [11-12]. A cup of cooked or sliced plantain has $49 \mathrm{mg}$ of magnesium $(\mathrm{Mg})$, and $716 \mathrm{mg}$ of potassium $(\mathrm{K})$, giving the body 15 percent of the recommended daily intake for each of these minerals [10-12]. The human body needs magnesium (Mg) for proper muscle contraction and nerve function, while potassium $(\mathrm{K})$ is an essential component in the body fluids [13]. A cup of plantains contains 5 to $10 \%$ of iron (Fe) needed for our body. Iron is an important nutrient to value to human health. It helps in carrying oxygen through the bloodstream [10]. Medically, plantain can be used to cure a lot of ailments including diabetes, sore throat, tonsillitis, diarrhea, and vomiting; and it is said to be a major diet in the production of soya-musa which can be used in the treatment of kwashiorkor [14].

Plantain flour is a good substitute for cassava flour. It can serve as a raw material for the production of cakes, chips, donuts, biscuit, bread and pancakes. Plantain flour is the product of dried and pulverized unripe plantain pulp. Among Yoruba-speaking area of Western part of Nigeria, it is known as "eluboagbagba". It is usually made into dough called "amala", having being reconstituted in boiling water [7]. The traditional method of producing plantain flour involves peeling the fruits with hand to get the pulp, slicing the pulp into thin slices, air drying the thin slices, and grinding the dried pulp into flour in a wooden mortar or a corn grinder. This technique is cumbersome and time consuming. It requires a lot of energy, and the quality, and quantity of plantain flour obtained by this means is adversely affected, thus the need for mechanization. In this research work, an improved plantain processing machine was fabricated from available materials in Nigeria. The fabricated machine will help to curb the problem of low quality, and quantity, hygiene, drudgery that are common with traditional methods of producing plantain flour in Nigeria.

Plantain processing involves several units and stages. Even though, different units of plantain processing machine such as pulverization, milling, etc., had been built over the year but a machine that comprises of all the units are not readily available in Nigeria. Several research work carried out by researchers on plantain processing machine is focused on pulverization of plantain. Zhou et al. [15] reported that, the fracture of a material, which is a result of the interaction between the blade edge and the material, depends both on the material properties and the knife geometry. Mahvash and Hayward [16] formulated a relationship between the cutting force and depth of cut during slicing. Atkins et al. [17] further clarified why there is a smaller cutting force required when pressing and slicing contrasted with the application of only pressing force while slicing. According to Yusuf and Abdullahi [18], slicing action could be accomplished through the following methods; slicing action with a sharp smooth edge, and tearing action with a rough serrated edge. In this present work, an improved plantain processing machine that comprises of all the units such as pulverization, milling, scrapping, drying, etc., was designed and fabricated.

\section{METHODOLOGY}

\subsection{Design Consideration}

In the design process, some important factors were considered. The factors considered include:

\subsubsection{Volume of Production}

One of the major constraints in the traditional method of producing plantain flour is the quantity of flour produced over a short period of time. To overcome the abovementioned factor, the following approach was taken;

i. The size of the rotating drum was increased to accommodate more plantain paste

ii. The rotation of the drum speed was increased

\subsubsection{Material Selection}

Stainless steel that is corrosion resistance and equally possesses strength and toughness was used for the pulverization unit. Other materials used and justification is shown in Table 1. 


\subsubsection{Safety}

The cutting blades were properly protected, and the heating coils were insulated to avoid operational hazards. The outlet was well positioned for easy access of the end product.

\subsubsection{Dryness Rate}

The heating coil is centrally located in the drum which gives a uniform distribution of heat

\subsubsection{Maintainability}

Bolts and nuts were for the drum dryer for easy replacement of the heating coils in case of damage. Bolts and nuts were used for to fasten all the distinct parts together on the machine frame which makes dismantling of the parts easier for replacement and maintenance. The positioning of the electric motors is such that it can easily be accessed and replaced without dismantling any other part.

\subsection{Description of the Machine Operation Procedure}

The machine has four major units; Pulverizer unit, Drum dryer unit, Scraper unit, and the miller unit

\subsubsection{The Pulverizer Unit}

Pulverizers are usually used to crush large material particles sizes into tiny granules. The pulverizer unit was fabricated with a stainless steel material. It consists of a shaft carrying four blades at the base, and that served as the blender. The shaft is connected to an electric motor by means of a single stage belt-pulley speed reduction mechanism. The main advantage of the use of this pulley system is that it prevents the fluid from leaking into the motor. The four blades in the pulverizer are arranged in two different orientations with two inclined upward at an angle of $45^{\circ}$ while the other two are designed like a stair with the vertical inclined downward also at an angle $45^{\circ}$. On peeling of an unripe plantain, the pulp was washed and sliced into pieces, and finally fed into the pulverizer unit. The electric motor is switched on and the plantains were pulverized for a period of 5 minutes. Thereafter, water was added to aid the crushing process after which the vessel was covered to prevent splattering of the paste. The plantain paste was ejected by means of a valve through a manifold into the tray. The essence of the inclusion of the manifold was to aid the spreading of the paste on the tray in the shortest possible time.

\subsubsection{The Drum Dryer}

The drum dryer is a stainless steel vessel that serves both as a conveyor and a dryer. It houses a heating system which supplies the heat that is used for drying the plantain paste. As the drum rotates about a hollow stationary shaft, the slurry is continuously spread on the drum. It is dried on the drum surface from where it is scraped off and transferred to the conventional grinding disc miller for further grinding into fine powder.

Table 1: Choice of Materials

\begin{tabular}{|c|c|c|c|}
\hline $\mathrm{S} / \mathrm{N}$ & $\begin{array}{l}\text { Component } \\
\text { Description }\end{array}$ & Material & Justification \\
\hline 1 & Metal Sheet & Stainless Steel & $\begin{array}{l}\text { *Ability to resist corrosion. } \\
\text { *At high temperatures it prevents scale and maintains } \\
\text { strength. }\end{array}$ \\
\hline 2 & Angle bar & $\begin{array}{l}\text { Mild steel (Low carbon } \\
\text { steel) }\end{array}$ & *Ability to withstand shear force and compressive force \\
\hline 3 & Pulley & Cast iron & *Tough, hard, low cost and has high strength \\
\hline 4 & $\begin{array}{l}\text { Shaft and Cutting } \\
\text { blade }\end{array}$ & Stainless steel & $\begin{array}{l}\text { *Ability to resistance corrosion } \\
\text { *Ability to withstand shear force and compressive } \\
\text { force. }\end{array}$ \\
\hline 5 & Belt fibre & Reinforced rubber & $\begin{array}{l}\text { *It is strong, flexible and durable, } \\
\text { *It has a high coefficient of friction }\end{array}$ \\
\hline 6 & $\begin{array}{l}\text { Flange } \\
\text { bearing }\end{array}$ & High carbon steel & $\begin{array}{l}\text { * Resistance to wear and corrosion, hard, tough and has } \\
\text { high strength. }\end{array}$ \\
\hline 7 & Bolt and Nut & Medium carbon steel & Strength and Toughness \\
\hline 8 & $\begin{array}{ll}\text { Main } & \text { Frame } \\
\text { Support } & \end{array}$ & Medium carbon steel & Strength and Toughness \\
\hline 9 & Pulverizer & Stainless steel & Resistance to corrosion, strength and toughness \\
\hline 10 & Drum Dryer & Stainless & Resistance to corrosion, strength and toughness \\
\hline
\end{tabular}




\subsubsection{The Scraper}

The scraper is a stainless steel plate. It performs two major functions; it scraped the dried plantain flakes, and also served as the in-feed for the miller which grinds the flakes into the flour. The scraper is supported by springs for the purpose of easy return to the set position in case of distortion.

\subsubsection{The Miller}

The miller is made up of a screw conveyor. The miller unit is where the final grinding takes place. After that, the plantain flower is collected, packaged and stored.

\subsection{The Drive Mechanism of the Machine}

Three electric motors with power rating of $2 \mathrm{hp}$ each were used in this machine. A three phase electric motor was used because it is more economical and uses less conductor material to transmit electrical power. The first electric motor drives the pulverizer shaft holding the blades. It uses a single stage belt-pulley speed reduction system. The second electric motor drives the drum dryer and it has a gear reduction mechanism to reduce the motor output speed. And the third electric motor is used to drive the miller in order to ensure effective grinding speed for the miller.

\subsection{Design Calculation}

\subsubsection{Design of Puverizer Capacity}

$$
V=\pi D_{p}^{2} \frac{H_{p}}{4}=0.0320 \mathrm{~m}^{3}
$$

Using density, mass, and volume relationship;

$$
\rho=\frac{M}{V}
$$

Thus, the maximum mass of plantain that the vessel can hold. But the density of plantain mixed with water is determined as $1000 \mathrm{~kg}$ [19]. $M=0.0320 \times 1000=$ $32.00 \mathrm{~kg}$

\subsubsection{Determination of the Pulverizer Outlet Flow Rate}

The pulverizer outlet flow rate, $Q_{\mathrm{p}}$ is given by equation (3);

$$
Q_{p}=\rho V_{0} A_{0}
$$

$A_{0}=\pi \frac{D_{0}^{2}}{4} \quad Q_{p}=1000 \times 0.00181 \times 0.02=0.0362 \mathrm{~kg} /$ $s=130.32 \mathrm{~kg} / \mathrm{hr}$.

\subsubsection{Design of Crushing/Grinding Force}

The crushing/grinding force is the force requires to pulverized/milled the plantains to the desire sizes and is given by equation (4).

$$
T=F r
$$

\subsubsection{Design of Total Power Required by the Machine}

The total power required to pulverize, mill, dried, and scrape the plantains is the given by equation (5)

$$
P_{T}=P+Q_{d}
$$

where,

$$
\begin{aligned}
& P= \frac{F \pi D N}{60} \\
& Q_{d}=h_{h f} \pi D L \Delta \theta
\end{aligned}
$$

But,

$F=m a=32.00 \mathrm{~kg} \times 10 \mathrm{~ms}^{-2}=320 \mathrm{~N}, \quad \mathrm{P} \quad=$ 1809.792 $\mathrm{W}$ and $Q_{d}=2082.87 \mathrm{~W}$

Therefore, total power required = $1809.792 \mathrm{~W}+2082.87 \mathrm{~W}=3892.662 \mathrm{~W}$

Too large or extremely small value of safety factor has its drawbacks. Choosing a safety of factor depends on the system in question and what conditions the drive and motor are expected to operate. A safety of factor of 1.4-2.25 is recommended, however in this research work, a safety of factor of 1.4 was used.

Power required $=1.4 \times 3892.662 \mathrm{~W}=5449.73 \mathrm{~W}$

\subsubsection{Design Calculations of the Drum Dryer Belt}

Figure 1 shows the belt- pulley double reduction mechanism.

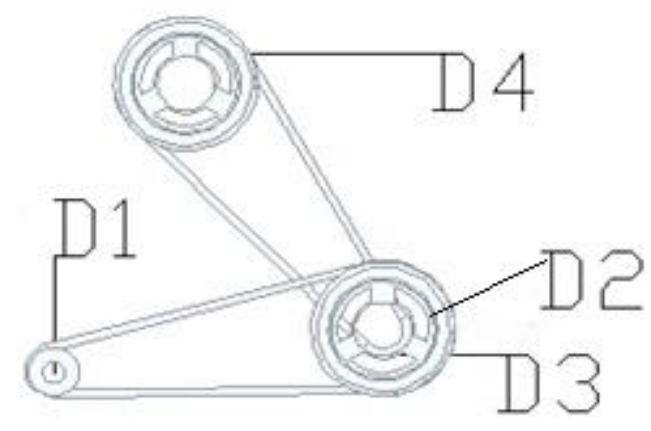

Figure 1: Belt Pulley Double Reduction Mechanism

For the compound belt drive shown above, the velocity ratio is given by equation (8)

$$
\begin{gathered}
\frac{\mathrm{N} 4}{\mathrm{~N} 1}=\frac{\mathrm{D} 1 \times \mathrm{D} 3}{\mathrm{D} 2 \times \mathrm{D} 4} \\
D_{4}=\frac{\mathrm{D} 1 \times \mathrm{D} 3 \mathrm{~N} 1}{\mathrm{D} 2 \times \mathrm{N} 4}=\frac{150 \times 50 \times 1400}{75 \times 480}=300 \mathrm{~mm}
\end{gathered}
$$

The belt length for the first reduction system is given by equation (9),

$$
L=\pi \frac{\left(D_{1}+D_{2}\right)}{2}+2 X+\frac{\left(D_{1}-D_{2}\right)^{2}}{4 X}=1.5 m
$$

\subsubsection{Design of the Blades}

If an average crushing pressure(C) acts on the blade, the force, (F) acting on the blade would be equal to the average crushing pressure multiplied by the area of the 
blade $\left(A_{b}\right)$ given by equation (10). The average crushing pressure was determined experimentally as 0.0804MPa by Afuwape et al., [20].

$$
\begin{aligned}
& A_{b}=e t_{1} \\
& F=\text { Cet }_{1}
\end{aligned}
$$

Assumption: Since all the four blades with length (e) and thickness $\left(t_{1}\right)$ are straight and extend from the shaft, the resultant of the average force, (F) will act at the centre of the blade such that the torque, (T) of any two blades on the same axis( $\mathrm{x}$ and $\mathrm{y})$ of torque $\left(\mathrm{T}_{\mathrm{x}}\right)$ and torque $\left(\mathrm{T}_{\mathrm{y}}\right)$ about the centre of the shaft would be equal.

$$
T=\left(\frac{e}{2}+d+\frac{e}{2}\right)=(e+d) F=(e+d) \operatorname{Cet}_{1}
$$

But the torque is determined by [21]

$$
T=\frac{60 P}{2 \pi N_{2}}
$$

Where: From speed reduction formula given by equation (14) [21]

$$
N_{2}=N_{1} \times \frac{D_{1}}{D_{2}}=720 \mathrm{rpm}
$$

Hence, $T=\frac{60 \times 2533.7088}{2 \pi \times 720}=33.60 \mathrm{Nm}$

But, from equation (12), $T=T_{x}=(e+d)$ Cet $_{1}$

$$
d=\frac{T_{x}}{\text { Cet }_{1}}-e=0.024 m
$$

Therefore, the diameter of the shaft is $24 \mathrm{~mm}$.

The solid isometric model and fabricated improved plantain processing machine are shown in Figure 2 and Figure 3 respectively.

\subsection{Performance Evaluation of the Machine}

The mass of plantain used $=32.00 \mathrm{~kg}$

Mass of pure water sachet $=0.5 \mathrm{~kg}$ (one sachet)

Ten pure water sachets was used

Thus,

Mass of water added, $\mathrm{mw}=5 \mathrm{k}$

Mass of water in unripe plantain is $61 \%$ of its total mass [7] $=0.61 \times 32=19.52 \mathrm{~kg}$

Total mass $=\mathrm{m}_{\mathrm{p}}+\mathrm{m}_{\mathrm{w}}=32+5=37 \mathrm{~kg}$

Total mass of water $=19.25+5=24.25 \mathrm{~kg}$

$\%$ composition of water in the pulverized plantain pulp $=\frac{24.25}{37} \times 100 \%=65.54 \%$

Total time required for processing of plantain $=$ 15 minutes

To evaluate the machine for performance, $32 \mathrm{~kg}$ of harvested plantain collected from a local market in Nigeria was peeled and sliced into smaller particles for pulverization. The pulveriser vessel was powered and plantain fully loaded for pulverization to take place (Figure 4). $5 \mathrm{~kg}$ of water was added continuously for proper formation of plantain paste. The pulverization process took about five minutes for completion. The heater was switched on while the grinding process continues until the surface temperature of the drum rises to the set temperature $\left(110^{\circ} \mathrm{C}\right)$ of the thermostat. Finally, the puverizer gate was opened for collection of plantain paste.

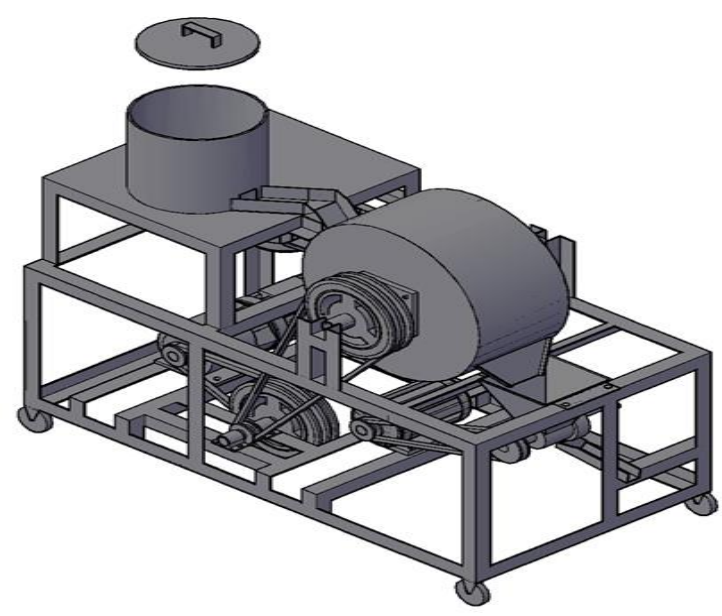

Figure 2: Solid Model Isometric View of the Improved Plant Processing Machine

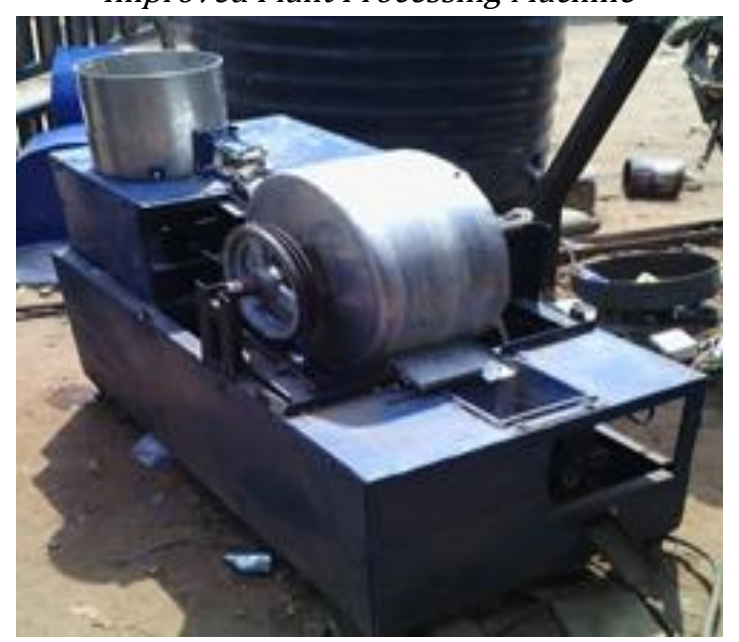

Figure 3: Fabricated Improved Plantain Processing Machine

Figure 5 shows the flow of paste through the pulverized outlet.

As the drum dryer rotates about a hollow stationary shaft, the plantain paste was continuously spread on the drum where it was allowed for proper drying to take place. The grinding disc miller was used for the grinding of the dried plantain paste into fine powder which is the plantain flour (Figure 6).

\section{RESULTS AND DISCUSSION}

The results obtained from the design calculation show that force, torque, and power of $320 \mathrm{~N}, 33.60 \mathrm{Nm}$, and 2533.7088W were required for operation of the machine. Also, it was observed, that the belt length for the first reduction system, and the second reduction system were the same (i.e., $1.5 \mathrm{~m}$ ). The percentage 
composition of water present in the mixture by mass was determined as $65.54 \%$.

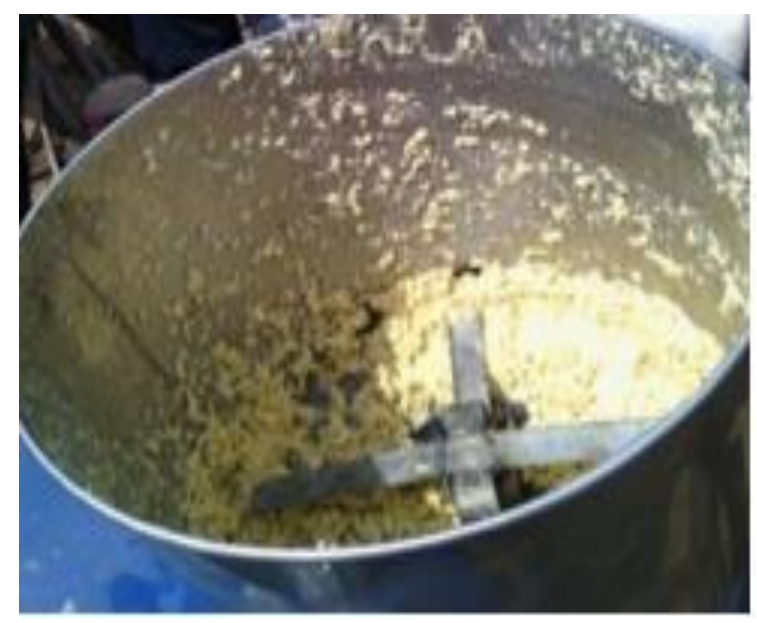

Figure 4: Pulverized Vessel and Product

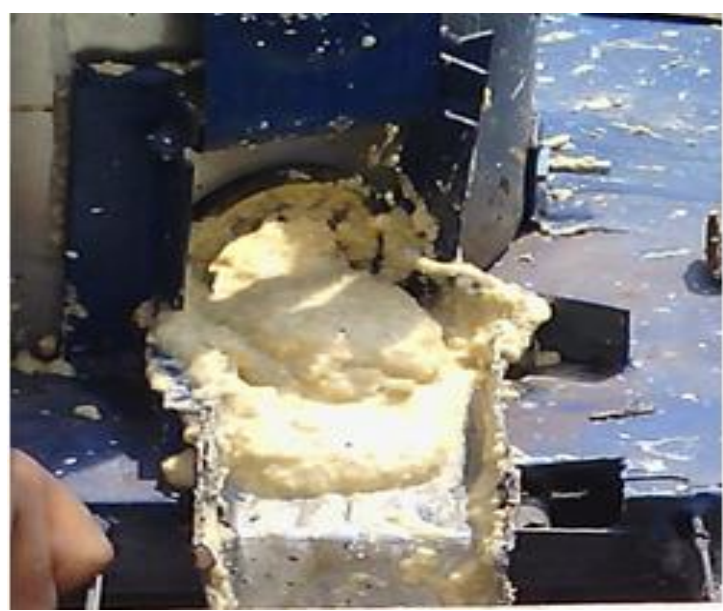

Figure 5: Flow of Plantain Paste through the Pulverizer

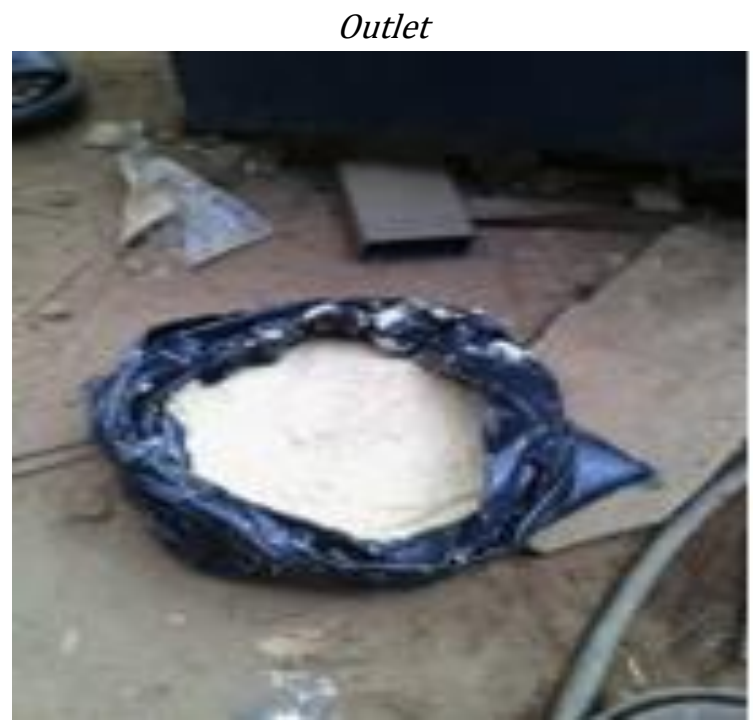

Figure 6: Plantain Flour

This implies that $65.54 \%$ of water composition was actually used in the pulverized plantain pulp. However, the plantain flour must be free from water, thus the drying drum unit. The total mass of flour produced from $32 \mathrm{~kg}$ of plantain was $4.29 \mathrm{~kg}$. It was observed that mass of water in $32 \mathrm{~kg}$ of plantain was $19.25 \mathrm{~kg}$. The total mass of plantain pulp was $37 \mathrm{~kg}$, and this was as a result of $5 \mathrm{~kg}$ of water used to ensure good quality paste formation from the pulverized process. The efficiency of the machine was calculated as follow;

$$
\eta_{p}=\frac{P_{1}}{P_{1}+P_{2}} \times 100 \%=81.87 \%
$$

The results obtained show that the machine is efficient. The machine throughput capacity (kg/sec) was obtained by expressing the mass of both proper and improper processed plantain flower per unit time.

$$
\begin{array}{r}
M T C=\frac{P_{1}+P_{2}}{t} \\
M T C=\frac{4.29+0.95}{15}=0.3493 \mathrm{~kg} / \mathrm{mins}
\end{array}
$$

The total time required for processing of plantain which includes time for pulverization unit, milling unit, scrapping unit, and drying unit were recorded as 15 minutes.

\section{CONCLUSION}

The usefulness of plantain and its end product are numerous. The unripe fruits are peeled, sliced, dried and made into powder which can be prepared into a staple consumable meal (Plantain fufu). However, the traditional method of producing plantain flour is cumbersome, unhealthy, and time consuming. In this research work, an improved plantain processing machine that comprises of all the processing units were successfully designed and fabricated. The machine was evaluated for performance. The outcome of the results show that plantain flour obtained from the improved machine was very dried and fine, thus the quality of the product was satisfactory. Also, all the unit part of the machine such as drying, pulverization, milling, etc., perform very well. Furthermore, the machine efficiency was high and this simply shows that the machine performance is satisfactory. Therefore, the machine can be used to process plantain for both domestic and commercial use.

\section{REFERENCES}

[1] Ayanwale, A. B., Fatunbi, A. O., and Ojo, M. "Innovation Opportunities in Plantain Production in Nigeria", Forum for Agricultural Research, pp. $1-44,2016$.

[2] Adeoye, I. B., Omobowale, A. O., Sulaiman, A. F., and Kemisola, O. A. "Plantain Value Chain Mapping in Southwestern Nigeria", Journal of Economics and Sustainable Development, Vol.4, No.16, pp.1-7, 2013. 
[3] Akinyemi, S. O. S. and Makinde, J. O. "Effect of sweet potato and melon intercrop on weed interference and productivity of plantain", Nigerian J. Weed Sci., 12, pp. 29-33, 1999.

[4] Akinsanmi, A.O., Oboh, G., Akinyemi, J.A., and Adefegha, A.S. "Assessment of the Nutritional, Anti nutritional and Antioxidant capacity of Uripe, ripe, and over ripe Plantain (Musa paradisiaca) Peels", International Journal of Advanced Research, Volume 3, Issue 2, pp. 63-72, 2015.

[5] Ikechukwu, C. U., Ibukun, B.I., and Zubair, O. M. "Design and Fabrication of an Electrically Powered Rotary Slicer for Raw Plantain Chips Production", American Journal of Engineering Research (AJER), Volume-03, Issue-04, pp-38-44, 2014.

[6] Arisa, N. U., Adelekan, A. O., Alamu, A. E. and Ogunfowora, E.J. "The effect of pretreatment of plantain (Musa Parasidiaca) flour on the pasting and sensory characteristics of biscuit", International Journal of Food and Nutrition Science, 2(1): pp.10-24, 2013.

[7] Zapkaa, H. D., Mak-Mensah, E. E., and Adubofor, J. "Production and Characterization of flour produced from ripe "apem" Plantain (musa sapientum L.var. paradisiacal; French horn) grown in Ghana", Journal of Agricultural Biotechnology and sustainable Development, 2(6), pp.92-99, 2010.

[8] Satimehin, A. A., Alakali, J. S., and Alabi, O. T., "Thinlayer Drying Characteristics of Plantain (Musa Paradisiaca) chips Agro Agro-Science, Journal of Tropical Agriculture, Food, Environment and Extension, Volume a, Number 1, pp.31-37, 2010

[9] Adamu, A. S., Ojo, I. O., and Oyetunde, J. G. "Evaluation of nutritional values in ripe, unripe, boiled and roasted plantain (musa paradisiacal) pulp and peel", European Journal of Basic and Applied Sciences, Vol. 4 No. 1, pp.9-17, 2017.

[10] Ukhum, M. E., and Ukpebor, I. E. "Production of instant plantain flour, sensory evaluation and Physico-chemical changes during storage, Food Chemistry, 42, pp. 287-299, 1991.

[11] Tomekpe, K., Kwa, M., Dzomeku, B. M., and Ganry, J. "CARBAP and innovation on the plantain banana in Western and Central Africa", International Journal of Agricultural Sustainability, 9(1), pp.264-273, 2011.
[12] Ekunwe, P. A., Ajayi, H. I. "Economics of Plantain Production in Edo State Nigeria", Research Journal of Agriculture and Biological Sciences, 6(6): pp.902-905, 2010

[13] Keulemans, J. "Sampling strategies and variability in fruit pulp micronutrient contents of West and Central African bananas and plantains (Musa species)", Journal of agricultural and food chemistry, 55(7), pp.2633-2644, 2007.

[14] Phillip, B., Shittu, A. M., Aiyelaagbe, I.O.O., and Adedokun, T. "Economic potentials of plantain and fluted pumpkin intercropping as a poverty reduction strategy in South-western Nigeria", World J. Agric. Sci., 5(5), pp.525- 534, 2009.

[15] Zhou, D., Claffee, M., Lee, K. and McMurray, G. “Cutting, 'by Pressing and Slicing', Applied to the Robotic Cut of Bio-materials, Part I: Modeling of Stress Distribution", Proceedings of the IEEE International Conference on Robotics and Automation (ICRA06), May 2006.

[16] Mahvash, M. and Hayward, V. Haptic Rendering of cutting: A fracture Mechnics Approach, Haptics-e, vol. 2, no. 3, pp. 1-12, 2001.

[17] Atkins, A. G., Xu, X., and Jeronimidis, G. "Cutting, by 'pressing and slicing,' of thin floppy slices of materials illustrated by experiments on cheddar cheese and salami, Journal of Materials Science, Springer Science + Business Media B.V., Formerly Kluwer Academic Publishers, vol. 39, pp. 27612766, 2004.

[18] Yusuf A. O., and Abdullahi I. "Development of Potato Slicing Machine”, Continental Journal of Engineering Sciences, 2: pp.49 - 57, 2007.

[19] Folade, K. O., Oyeyinka, S. A. "Colour, chemical and functional properties of plantain and banana flour as affected by drying method and maturity", Journal of Food Processing and Preservation, vol. 39, Issue, 6, 2014.

[20] Afuwape, O. F, Ebikade, G. E, Oguzie, C, Olaye, O, Osinowo, B.A. Design and Fabrication of a Prototype Plant for Processing Unripe Plantain, An unpublished B.Eng Thesis in the Department Of Mechanical Engineering, University Of Benin, October 2012.

[21] Khurmi, R. J., and Gupta, J. K. Machine Design, Eurasia Publishing House (pvt) Ltd, New Delhi, 2013. 